\title{
Effects of dietary menthol-rich bioactive lipid compounds on zootechnical traits, blood variables and gastrointestinal function in growing sheep
}

Amlan K. Patra ${ }^{1,2}$, Sebastian Geiger ${ }^{1}$, Katharina T. Schrapers ${ }^{3}$, Hannah-Sophie Braun ${ }^{3}$, Heidrun Gehlen ${ }^{4}$, Alexander Starke ${ }^{5}$, Robert Pieper ${ }^{6}$, Adam Cieslak $^{7}$, Malgorzata Szumacher-Strabel ${ }^{7}$ and Jörg R. Aschenbach ${ }^{1 *}$ (D)

\begin{abstract}
Background: The present study aimed at investigating the influence of 90\% menthol-containing plant bioactive lipid compounds (PBLC, essential oils) on growth performance, blood haematological and biochemical profile, and nutrient absorption in sheep. Twenty-four growing Suffolk sheep were allotted into three dietary treatments: Control (without PBLC), lower dose of PBLC (PBLC-L; $80 \mathrm{mg} / \mathrm{d}$ ) and higher dose of PBLC (PBLC-H; $160 \mathrm{mg} / \mathrm{d})$. Sheep in all groups were fed meadow hay ad libitum plus $600 \mathrm{~g} / \mathrm{d}$ of concentrate pellets for $28 \mathrm{~d}$.

Results: Average daily gain was not affected by treatment. Feeding of PBLC increased hay and total feed intake per $\mathrm{kg}$ body weight $(P<0.05)$. Counts of total leucocytes, lymphocytes and monocytes were not different among treatments. However, neutrophil count decreased $(P<0.05)$ in PBLC-H with a similar trend in PBLC-L $(P<0.10)$. Concentrations of glucose, bilirubin, triglycerides, cholesterol, urea and magnesium in serum were not different among sheep fed different doses of PBLC. However, serum calcium concentration tended to increase in PBLC-H $(P<0.10)$ and serum concentrations of aspartate \& asparagine $(P<0.01)$ and glutamate \& glutamine $(P<0.05)$ increased linearly with increasing PBLC dose. In ruminal epithelia isolated from the rumen after killing, baseline conductance $\left(G_{t} ; P<0.05\right)$ and short-circuit current $\left(I_{s c i} P<0.01\right)$ increased in both PBLC groups. Ruminal uptakes of glucose and methionine in the presence of $\mathrm{Na}^{+}$were not affected by the dietary PBLC supplementation. In the absence of $\mathrm{Na}^{+}$, however, glucose and methionine uptakes increased $(P<0.05)$ in PBLC-H. In the jejunum, Isc tended to increase in PBLC-H $(P<0.10)$, but baseline $G_{t}$ was not affected. Intestinal uptakes of glucose and methionine were not influenced by PBLC in the presence or absence of $\mathrm{Na}^{+}$.

Conclusion: The results suggest that menthol-rich PBLC increase feed intake, and passive ion and nutrient transport, the latter specifically in the rumen. They also increased serum concentrations of urea precursor amino acids and tended to increase serum calcium concentrations. Future studies will have to show whether some of these findings might be commonly linked to a stimulation of transient receptor potential (TRP) channels in the gastrointestinal tract.
\end{abstract}

Keywords: Electrophysiology, Essential oil, Feed intake, Growth performance, Nutrient uptakes

\footnotetext{
* Correspondence: joerg.aschenbach@fu-berlin.de

${ }^{1}$ Institute of Veterinary Physiology, Freie Universität Berlin, Oertzenweg 19b,

14163 Berlin, Germany

Full list of author information is available at the end of the article
}

(c) The Author(s). 2019 Open Access This article is distributed under the terms of the Creative Commons Attribution 4.0 International License (http://creativecommons.org/licenses/by/4.0/), which permits unrestricted use, distribution, and reproduction in any medium, provided you give appropriate credit to the original author(s) and the source, provide a link to the Creative Commons license, and indicate if changes were made. The Creative Commons Public Domain Dedication waiver (http://creativecommons.org/publicdomain/zero/1.0/) applies to the data made available in this article, unless otherwise stated. 


\section{Background}

Antibiotics have been used as feed additives in livestock and poultry shortly after their discovery from 1940's [1]. The widespread use of antibiotics as growth promoters has posed a threat due to the development of antibioticresistant pathogenic bacteria, which has led to bans or restricted use of antibiotics in several countries [2]. This restriction of antibiotics impacts on feed efficiency and growth performance of animals and causes increased incidences of intestinal diseases [1]. Therefore, several alternatives to antibiotic growth promoters including probiotics, prebiotics, enzymes, antimicrobial peptides and plant bioactive compounds have been extensively explored [3-5]. Plant bioactive agents have several beneficial properties including antimicrobial, antioxidant, immune-modulating and pharmacological activities, and thus have been evaluated as natural feed additives in farm animals $[3,6,7]$. They include flavonoids, tannins, saponins and plant bioactive lipid compounds (PBLC). The latter include primarily the commonly known "essential oils", which is a misleading term as "essential oils" are not biologically essential and many of them (including menthol) are solid at room temperature, i.e., not an oil. Natural PBLC seem sustainable options that have a history of safe use since ancient times [8]. In ruminants, some PBLC have shown promise to modulate ruminal fermentation favourably, resulting in improved production performance, health status, welfare and environmental advantages $[6,9,10]$.

We recently reviewed the beneficial effects of PBLC on gastrointestinal barrier and transport function, as well as on regulatory pathways involved in these processes [11]. To our knowledge, menthol has not been tested previously for such effects but some data is available from other PBLC. Regarding barrier function, for example, oregano oil fed to pigs upregulated occludin and zonula occludens-1 mRNA expression in the jejunum [12] and olive oil bioactive compounds increased the mRNA levels of E-cadherin-1, occludin and zonula occludens-1 in ileal mucosa of lipopolysaccharide-challenged pigs [13]. Regarding nutrient uptake from the gastrointestinal tract, cinnamaldehyde upregulated the jejunal gene expression of the sodium/glucose co-transporter SGLT-1 and the facilitated glucose transporter GLUT-2 [14], and capsicum oleoresin upregulated the mRNA expression of many genes involved in cell membrane channels and transporters in the ileum of pigs [15]. However, a direct proof for the functional relevance of these molecular changes has rarely been provided.

At variance, certain PBLC such as menthol have been shown to directly stimulate the function of bovine transient receptor potential (TRP) channels, which are involved in cation transport across gastrointestinal epithelia $[16,17]$. There are also reports that flavonoid compounds could functionally impair nutrient transport mechanisms in the gastrointestinal tract; e.g., quercetin3-O-glucoside, trans-resveratrol and $\varepsilon$-viniferin hindered glucose transport in porcine intestinal epithelial cells in vitro $[18,19]$.

Proceeding from the known role of menthol as TRP channel agonist in the gastrointestinal tract of ruminants $[16,17]$, we hypothesized that menthol-rich PBLC could have direct effects on ruminal and intestinal epithelia that may be relevant for nutrient absorption and consequently feed utilization beyond the already described effects on ruminal microbial fermentation $[20,21]$. Such effects could also be complementary to other known beneficial activities of menthol-containing PBLC such as antioxidant and immunomodulatory effects [22]. Consequently, this study was designed to investigate the effects of PBLC with menthol as the main compound on feed intake and growth performance in growing sheep with an additional focus on ruminal and intestinal glucose and methionine (Met) absorption, blood cell count, and on serum metabolites with relevance to nutrient and mineral homeostasis.

\section{Material and methods}

\section{Experimental design, animals and management}

Twenty-four growing Suffolk sheep (15 females and 9 males) were purchased from a local farmer. Sheep were group-fed and adapted to a control diet for at least $14 \mathrm{~d}$ before allocating them to different diets. At the start of the experiment, body weight (BW) and age of the animals were $32.9 \pm 3.44 \mathrm{~kg}$ and $121 \pm 3.75 \mathrm{~d}$, respectively. The experiment was conducted in two runs with 12 sheep in each run. Sheep were equally allocated into three dietary treatments in each run in a randomized block design based on initial body weight and sex, each treatment containing 5 females and 3 males. The three groups were 1) Control diet (without PBLC), lower dose of PBLC (PBLC-L; $80 \mathrm{mg} / \mathrm{d}$ ) and higher dose of PBLC (PBLC-H; $160 \mathrm{mg} / \mathrm{d})$. In each run, sheep were kept in four indoor pens with each pen containing three separate feeding stations. Sheep were equipped with electronic transponders on their neck collar that opened the automatic locking gates of one transponder-operated feeding station (Hütter GbR, Marktbergel, Germany). They were trained for 2 to $4 \mathrm{~d}$ until they recognized their individually allocated feeders easily. Pens had concrete floor with wood shavings as bedding material. The room was lighted by natural day-light from glass windows along with artificial light from 06:00 to 18:00 h.

\section{Diet preparation and feeding}

During the adjustment period to the automatic feeding system, all sheep were fed the pelleted Control concentrate $(400 \mathrm{~g} / \mathrm{d})$ and ad libitum meadow hay (without 
chopping). Thereafter, the experiment started with providing the three different concentrates. The amounts of concentrates were gradually increased: $450 \mathrm{~g} / \mathrm{d}$ for the first $3 \mathrm{~d}, 525 \mathrm{~g} / \mathrm{d}$ for the next $3 \mathrm{~d}$, and $600 \mathrm{~g} / \mathrm{d}$ thereafter. Hay was provided in the forage storage containers of the feeding stations for ad libitum intake. Ingredients and chemical composition of the three concentrates were identical, except that concentrates of the PBLC-L and PBLC-H groups were added with PBLC at 133.3 and $266.7 \mathrm{mg} / \mathrm{kg}$ concentrates (as-fed basis; Table 1). The PBLC contained $900 \mathrm{~g} / \mathrm{kg}$ menthol together with other minor PBLC components. The PBLC components were added to the concentrates as a commercial premix (OAX17, PerformaNat GmbH, Berlin, Germany) with ground corn as carrier. Ad libitum hay plus $600 \mathrm{~g} / \mathrm{d}$ pelleted concentrate diets were fed to meet nutrient requirements according to NRC [23]. Water was available at all times from push-button water troughs. The daily dose of PBLC was supplied with the concentrate pellets

Table 1 Ingredient and chemical composition of pelleted concentrates and hay fed to sheep

\begin{tabular}{|c|c|c|c|c|}
\hline \multirow[t]{2}{*}{ Item } & \multicolumn{3}{|c|}{ Concentrate $^{a}$} & \multirow[t]{2}{*}{ Hay } \\
\hline & Control & PBLC-L & PBLC-H & \\
\hline \multicolumn{5}{|l|}{ Ingredient composition, g/kg as-fed } \\
\hline Corn & 305 & 295 & 285 & \\
\hline Barley & 305 & 305 & 305 & \\
\hline Soybean meal & 348 & 348 & 348 & \\
\hline Molasses & 30 & 30 & 30 & \\
\hline Mineral and vitamin premix ${ }^{\mathrm{b}}$ & 5 & 5 & 5 & \\
\hline Salt & 2 & 2 & 2 & \\
\hline Limestone & 5 & 5 & 5 & \\
\hline PBLC premix ${ }^{c}$ & 0 & 10 & 20 & \\
\hline \multicolumn{5}{|l|}{ Chemical composition } \\
\hline Dry matter (DM), g/kg as-fed & 914 & 915 & 912 & 923 \\
\hline Organic matter, g/kg DM & 949 & 950 & 948 & 958 \\
\hline Crude protein, g/kg DM & 259 & 257 & 259 & 108 \\
\hline Ether extract, g/kg DM & 30.8 & 25.1 & 25.8 & 9.60 \\
\hline Neutral detergent fibre, $\mathrm{g} / \mathrm{kg} \mathrm{DM}$ & 125 & 140 & 152 & 641 \\
\hline Acid detergent fibre, g/kg DM & 65.4 & 74.6 & 70.7 & 374 \\
\hline Crude fibre, g/kg DM & 48.9 & 41.7 & 43.0 & 332 \\
\hline Calcium, g/kg DM & 5.31 & 5.36 & 5.83 & 3.11 \\
\hline Phosphorus, g/kg DM & 5.09 & 4.81 & 4.74 & 2.08 \\
\hline
\end{tabular}

${ }^{a}$ Control: without PBLC; PBLC-L: lower dose $(133.3 \mathrm{mg} / \mathrm{kg})$ of PBLC; and PBLC-H: higher dose $(266.7 \mathrm{mg} / \mathrm{kg})$ of PBLC

${ }^{\mathrm{b}}$ Mineral and vitamin premix (Spezialfutter Neuruppin Ltd., Neuruppin, Germany), containing per kilogram dry matter: $160 \mathrm{~g}$ calcium, $40 \mathrm{~g}$ phosphorus, $100 \mathrm{~g}$ sodium, $30 \mathrm{~g}$ magnesium, 500,000 IU vitamin A, 50,000 IU vitamin $D_{3}, 500 \mathrm{mg}$ vitamin $E$ (as alpha-tocopherol acetate), $4500 \mathrm{mg}$ zinc (as zinc oxide), $500 \mathrm{mg}$ manganese (as $\mathrm{Mn}$-(II)-oxide), $20 \mathrm{mg}$ cobalt (as Co-(II)carbonate), $20 \mathrm{mg}$ iodine (as calcium iodate), and $35 \mathrm{mg}$ selenium (as sodium selenite)

'PBLC premix (OAX17, PerformaNat GmbH, Berlin, Germany; containing $13.3 \mathrm{~g}$ $\mathrm{PBLC} / \mathrm{kg}$ corn grains) that were provided in three equal portions of $200 \mathrm{~g}$ each at 07:00, 11:00 and 15:00 h. Concentrate mixtures were pelleted below $50{ }^{\circ} \mathrm{C}$ to prevent loss of PBLC during pelleting. Concentrate pellets were stored in air-tight bags.

\section{Body weight, feed intake and feed sampling}

Body weight of sheep was measured at 7-day intervals at 09:30 to 10:00 h. Body weight (BW) and BW changes of the first week were not used to account for potential rumen fill effects due to dietary shifts. As such, initial and final body weight, and average daily gain are presented over the last $21 \mathrm{~d}$ of the experiment. Concentrate intake was recorded routinely every day; there were no orts of concentrate. Orts of hay were collected before concentrate feeding in a bag and pooled per animal and per week. Hay intake was measured at weekly interval subtracting the amount of hay orts from the amount of hay offered in a week. Intake is reported on a dry matter basis over the last $21 \mathrm{~d}$ of the feeding trial, again, considering the first week as adaptation to the diets. Hay samples were obtained weekly and pooled together per run. Concentrate and orts samples were also obtained weekly and pooled per run and per treatment. Samples of hay, orts and concentrates were kept at $-20^{\circ} \mathrm{C}$ until analysis.

\section{Blood cell count and biochemical profile}

Blood samples were collected from the jugular vein using two 9-mL tubes (Vacuette ${ }^{\circ}$ Greiner Bio-One $\mathrm{GmbH}$, Kremsmüster, Austria) between 09:30 to 10:00 h, i.e. $2.5 \mathrm{~h}$ after the morning feeding of concentrates, on $\mathrm{d}$ 0 ( $1 \mathrm{~d}$ before actual start of the experiment) and on $\mathrm{d} 27$. One vacutainer tube with clot activator was used for harvesting of serum and another tube with K3-EDTA was used for haematological profile. Vacutainers for serum were allowed to clot for $30 \mathrm{~min}$ at room temperature and then put on ice. Serum was separated by centrifugation $\left(1,500 \times g\right.$ at $4{ }^{\circ} \mathrm{C}$ for $\left.10 \mathrm{~min}\right)$ within $1 \mathrm{~h}$ after blood sampling and immediately stored at $-20^{\circ} \mathrm{C}$ until analysis. The serum concentrations of glucose, triglycerides, bilirubin, cholesterol, urea, calcium and magnesium were measured by a Cobas C 311 (Roche Diagnostics Deutschland GmbH, Mannheim, Germany) in the laboratory of the Clinic for Internal Veterinary Medicine of Leipzig University (Leipzig, Germany) with ready-to-use $e$ pack reagents (Roche Diagnostics Deutschland $\mathrm{GmbH}$ ). Haematological profile of blood was analysed within $2-4 \mathrm{~h}$ using an automated haematology analyser (CA530-VET, Boule Medical, Stockholm, Sweden). Briefly, the analyser determined cell counts and volumes by electronic impedance. Mean corpuscular volume, mean platelet volume and red cell distribution width were determined from the size distribution curve of erythrocytes or platelets automatically. Haemoglobin concentration was determined photometrically while 
mean corpuscular haemoglobin concentration and mean corpuscular haemoglobin were calculated using established equations by the in-built software of the analyser. Packed cell volume (PCV) was determined by the microcentrifugation method. The PCV samples were centrifuged at 3,400×g for $15 \mathrm{~min}$ (Haematokrit 210, Hettich, Tuttlingen, Germany).

\section{Amino acid analysis in serum}

The concentrations of free amino acids in serum samples were determined by chromatographic UPLC analysis [24]. The derivatization procedure followed the instruction of the kit AccQ•Tag reagent (Waters, Milford, MA, USA). Briefly, $50 \mu \mathrm{L}$ serum sample was transferred to screw neck max recovery vials (Waters, Milford, MA, USA), $20 \mu \mathrm{L}$ of borate buffer was added to each vial and the solution was briefly vortexed. Following this, $20 \mu \mathrm{L}$ working internal standard, $90 \mu \mathrm{L} 10 \mathrm{mmol} / \mathrm{L}$ hydrochloric acid and $20 \mu \mathrm{L}$ of $10 \mathrm{mmol} / \mathrm{L}$ 6-aminoquinolyl-N-hydroxysuccinimidyl carbamate in acetonitrile were added to the vials and the solution was vortexed again for $10 \mathrm{~s}$ before being heated at $55^{\circ} \mathrm{C}$ using thermo-block MD-02 N (Major Sciences, Saratoga, CA, USA) for $10 \mathrm{~min}$. The standard solution (Amino Acid Standard H; ThermoScientific, Rockford, IL, USA) of amino acids mixture contained His, Ser, Arg, Gly, Asp, Glu, Thr, Ala, Pro, Lys, Tyr, Val, Ile, Leu, Phe and Met at a concentration of $2.5 \mathrm{mmol} / \mathrm{L}$, whereas concentration of Cys was $1.25 \mathrm{mmol} / \mathrm{L}$. With this method, Gln is analyzed together with Glu, and Asn is analysed together with Asp. DL-2-aminobutyric acid (Sigma-Aldrich; St. Loius, MO, USA) was used as an internal standard. The UPLC system (ACQUITY; Waters, Milford, MA, USA) fitted with photodiode array detector was used for determination of free amino acids. Chromatographic separation was obtained with the AccQ-Tag Ultra C-18 column (2.1 $\mathrm{mm} \times 100 \mathrm{~mm} ; 1.7 \mu \mathrm{m})$. The flow rate was $0.6 \mathrm{~mL} / \mathrm{min}$ and a binary gradient system with two eluents was used for separation, eluent A (consisting of $25 \mathrm{~mL}$ concentrated AccQ-Tag Ultra diluted in $500 \mathrm{~mL}$ MilliQ water) and eluent B (Amino acids analysis; AccQ-Tag Ultra; Waters). The gradient system was as follows: $0-0.64 \mathrm{~min}, 99.9 \% \mathrm{~A}$; 0.64-6.71 min, 90.9\% A; 6.71-7.74 min, 78.8\% A; 7.74$10.11 \mathrm{~min}, 40.4 \% \mathrm{~A} ; 10.11-12 \mathrm{~min}, 99.9 \% \mathrm{~A}$. The injection volume was $1 \mu \mathrm{L}$, and the column temperature was set at $55^{\circ} \mathrm{C}$. The amino acid peaks in the samples were identified by comparison to the retention times of the amino acid peaks of the standard solution. Thereafter, the concentrations of the amino acids in the samples were calibrated using the peak area of the standard amino acid concentrations (Empower 2 software; Waters).

\section{Feed analysis}

Chemical composition of feed and orts samples was analysed following standard methods [25]. Content of dry matter was determined in a drying cabinet (VDLUFA MB III 3.1), crude ash in a muffle furnace at $550{ }^{\circ} \mathrm{C}$ (VDLUFA III 8.1), ether extract by the Soxhlet method with hydrolysis (VDLUFA MB III 5.1.1) and crude protein $(\mathrm{CP})$ by incineration method (VDLUFA MB III 4.1.2). Acid detergent fibre expressed exclusive of residual ash $\left(\mathrm{ADF}_{\mathrm{om}}\right)$ was determined by using Fibertec ${ }^{\mathrm{mm}}$ 8000 (FOSS, Hilleroed, Denmark; method, VDLUFA MB III 6.5.2). Neutral detergent fibre content (comparable to assay with heat-stable amylase and expressed exclusive of residual ash; $\mathrm{aNDF}_{\mathrm{om}}$ ) was estimated by near-infrared spectroscopy according to the method VDLUFA MB III 31.2. Dietary calcium and phosphorous contents were determined by inductively coupled optical emission spectroscopy (ICP-OES; DIN EN ISO 11885:2009-09).

\section{Uptake of glucose and methionine}

In the week following the 28-d feeding trial, animals were maintained on their dietary protocol according to their group assignment until captive bolt stunning and killing by exsanguination. In a rotating order among groups, two animals were slaughtered per day; one animal $2 \mathrm{~h}$ after the morning feeding and a second animal $2 \mathrm{~h}$ after the noon feeding. Preparation and incubation of ruminal and intestinal tissues largely followed previously described protocols [26]. Pieces from the ventral ruminal sac and mid-jejunum were dissected after slaughter and rinsed with $\mathrm{NaCl}$ solution $\left(9 \mathrm{~g} / \mathrm{L} ; 38^{\circ} \mathrm{C}\right)$. Tissue pieces were transferred to transport solution (Table 2) pre-gassed with carbogen $\left(5 \% \mathrm{CO}_{2}\right.$ and $95 \%$ $\mathrm{O}_{2}$ ) at $38^{\circ} \mathrm{C}$, where epithelia were stripped off the muscular and serosal layers. The stripped epithelia were placed in a Dewar container with fresh transport buffer (carbogen-gassed; $38^{\circ} \mathrm{C}$ ) and transported to the laboratory within $30 \mathrm{~min}$. Epithelia were mounted in Ussing chambers with an exposed area of $3.14 \mathrm{~cm}^{2}$. Total time taken from euthanasia to mounting in Ussing chambers was $\sim 45 \mathrm{~min}$. The chambers contained $16 \mathrm{~mL}$ incubation solution on the serosal and the mucosal side each (Table 2). The serosal solution was the same for all treatments and contained glucose $(10 \mathrm{mmol} / \mathrm{L})$ and $\mathrm{Na}^{+}$ $(135 \mathrm{mmol} / \mathrm{L})$. The mucosal solutions were all glucosefree, and $\mathrm{Na}^{+}$was either present $(135 \mathrm{mmol} / \mathrm{L})$ or completely replaced by $N$-methyl- $D$-glucamine $\left(\mathrm{NMDG}^{+}\right)$. To simulate the rumen conditions in vivo, mucosal solutions for ruminal epithelia contained short-chain fatty acids (SCFA) and were titrated to $\mathrm{pH}$ 6.4. All solutions were circulated by a gas lift system $\left(5 \% \mathrm{CO}_{2}\right.$ and $95 \%$ $\mathrm{O}_{2}$ ) and maintained at $38^{\circ} \mathrm{C}$ with the aid of thermostated water jackets around the solution reservoirs. Two chambers per epithelial tissue (rumen and jejunum) and per each mucosal buffer $\left(\mathrm{Na}^{+}\right.$-containing and $\mathrm{Na}^{+}$-free) were used for uptake measurements in each sheep. 
Table 2 Chemical composition of mucosal and serosal buffers used in the Ussing chamber study

\begin{tabular}{|c|c|c|c|c|c|}
\hline \multirow[t]{2}{*}{ Item } & \multirow{2}{*}{$\begin{array}{l}\text { T\&S } \\
\text { solution }\end{array}$} & \multicolumn{2}{|c|}{ Mucosal solutions, rumen } & \multicolumn{2}{|c|}{ Mucosal solutions, intestine } \\
\hline & & $\overline{\mathrm{Na}^{+} \text {-containing }}$ & $\overline{\mathrm{Na}^{+} \text {-free }}$ & $\mathrm{Na}^{+}$-containing & $\mathrm{Na}^{+}$-free \\
\hline \multicolumn{6}{|l|}{ Composition, mmol/L } \\
\hline $\mathrm{CaCl}_{2}$ & 1.8 & 1.8 & 1.8 & 1.8 & 1.8 \\
\hline $\mathrm{MgCl}_{2}$ & 1.0 & 0 & 0 & 0 & 0 \\
\hline HEPES, free acid & 10.0 & $10.0^{\mathrm{a}}$ & $10.0^{\mathrm{a}}$ & 10.0 & 10.0 \\
\hline $\mathrm{NaCl}$ & 70.0 & 70.0 & 0.0 & 70.0 & 0.0 \\
\hline $\mathrm{HCl}$ & 0.0 & 17.0 & 87.0 & 2.0 & 72.0 \\
\hline Na-acetate & 0.0 & 25.0 & 0.0 & 0.0 & 0.0 \\
\hline Acetic acid & 0.0 & 0.0 & 25.0 & 0.0 & 0.0 \\
\hline Na-propionate & 0.0 & 10.0 & 0.0 & 0.0 & 0.0 \\
\hline Propionic acid & 0.0 & 0.0 & 10.0 & 0.0 & 0.0 \\
\hline Na-butyrate & 0.0 & 5.0 & 0.0 & 0.0 & 0.0 \\
\hline Butyric acid & 0.0 & 0.0 & 5.0 & 0.0 & 0.0 \\
\hline Na-gluconate & 40.0 & 0.0 & 0.0 & 40.0 & 0.0 \\
\hline Gluconic acid & 0.0 & 0.0 & 0.0 & 0.0 & 40.0 \\
\hline NMDG free base & 5.0 & 2.0 & 112 & 7.0 & 117 \\
\hline $\mathrm{KH}_{2} \mathrm{PO}_{4}$ & 0.4 & 0.4 & 0.4 & 0.4 & 0.4 \\
\hline $\mathrm{K}_{2} \mathrm{HPO}_{4}$ & 2.4 & 2.4 & 2.4 & 2.4 & 2.4 \\
\hline $\mathrm{NaHCO}_{3}$ & 25.0 & 25.0 & 0.0 & 25.0 & 0.0 \\
\hline Cholin- $\mathrm{HCO}_{3}$ & 0.0 & 0.0 & 25.0 & 0.0 & 25.0 \\
\hline Enrofloxacine & 0.0278 & 0.0278 & 0.0278 & 0.0278 & 0.0278 \\
\hline Mannitol & 0 & 19.0 & 19.0 & 9.0 & 9.0 \\
\hline Glucose & 10.0 & 0 & 0 & 0 & 0 \\
\hline Osmolarity, mOsmol/L & 288 & 288 & 288 & 288 & 288 \\
\hline $\mathrm{pH}$ & 7.4 & 6.4 & 6.4 & 7.4 & 7.4 \\
\hline
\end{tabular}

HEPES: 4-(2-hydroxyethyl)-1-piperazine ethanesulfonic acid; NMDG: $N$-methyl-D-glucamine; T\&S: Transport and serosal

${ }^{a}$ Ruminal mucosal buffer contained MES (2-morpholinoethanesulfonic acid) free acid instead of HEPES free acid

Approximately $10 \mathrm{~min}$ after mounting, all epithelia were set to short-circuit mode, i.e. the transepithelial potential difference $\left(P D_{\mathrm{t}}\right)$ was clamped to $0 \mathrm{mV}$ by the aid of a computer-controlled voltage-clamp device (Mussler Scientific Instruments, Aachen, Germany). The inverse value of the current required to clamp $P D_{\mathrm{t}}$ to $0 \mathrm{mV}$ was continuously recorded as short-circuit current $\left(I_{\mathrm{sc}}\right)$, representing the energy-dependent charge transfer across the epithelium. Additionally, transepithelial conductance $\left(G_{t}\right)$ as a measure of ion conductivity was measured from the changes in $P D_{\mathrm{t}}$ after bipolar current pulses $(100 \mu \mathrm{A}$ for $300 \mathrm{~ms}$ at 6 -s intervals) according to Ohm's law $\left(G_{\mathrm{t}}=\delta I / \delta P D_{\mathrm{t}}\right)$ [26]. All epithelia were equilibrated for about $30 \mathrm{~min}$ under short-circuit conditions with $\mathrm{Na}^{+}$-containing buffers at the mucosal side until $G_{\mathrm{t}}$ stabilized. The plateau values of $G_{\mathrm{t}}$ and $I_{\mathrm{sc}}$ after equilibration were averaged over $1 \mathrm{~min}$ and used for statistical comparison among animals.

After equilibration, uptake measurements were initiated with modifications from previously established protocols [27]. The mucosal solution was discarded and $\mathrm{Na}^{+}$-free or $\mathrm{Na}^{+}$-containing mucosal solutions were filled up in accordance with chamber assignments for both ruminal and intestinal tissues. Partially radiolabeled $\left[{ }^{3} \mathrm{H}\right]$ $D$-glucose $(74 \mathrm{kBq} / 16 \mathrm{~mL})$ and $\left[{ }^{14} \mathrm{C}\right]-L$-methionine $(37$ $\mathrm{kBq} / 16 \mathrm{~mL}$ ) were added simultaneously to final concentrations of $50 \mu \mathrm{mol} / \mathrm{L}$ ( $L$-methionine) and $200 \mu \mathrm{mol} / \mathrm{L}$ (D-glucose) to the mucosal solution. Hot samples $(100 \mu \mathrm{L})$ were taken from the mucosal solution in duplicate at $20 \mathrm{~s}$. After $1 \mathrm{~min}$ incubation, the solutions on both sides of the epithelium were drained out and the epithelium was flushed with ice-cold intestinal $\mathrm{Na}^{+}$-free solution three times to wash off all extracellularly adhering radioactivity.

The epithelia from the Ussing chambers were quickly transferred on the top of $15 \mathrm{~mL}$ Falcon tubes (exposed area, $1.77 \mathrm{~cm}^{2}$ ) prefilled with $5 \mathrm{~mL}$ of $0.2 \mathrm{~mol} / \mathrm{L} \mathrm{NaOH}$ and $0.25 \%$ SDS solution. The tissues were vortexed for 2 min to lyse cells and the tubes were placed on the rotator for another $30 \mathrm{~min}$. The lysate was collected into 15 
$\mathrm{mL}$ Falcon tubes and centrifuged at $5,000 \times g$ and $4{ }^{\circ} \mathrm{C}$ for 20 min. Supernatant samples $(800 \mu \mathrm{L})$ were mixed with $3 \mathrm{~mL}$ Aquasafe 300 (Zinsser Analytic GmbH, Eschborn, Germany) for determination of radioactivity using a liquid scintillation counter (LKB Wallace-Perkin-Elmer, Überlingen, Germany). The specific activity (cpm per pmol substrate) were calculated from the radioactivity of the hot samples and used to calibrate the radioactivity of cold samples to uptakes of glucose and methionine. Uptakes were expressed as $\mathrm{pmol} /\left(\mathrm{cm}^{2} \cdot \mathrm{min}\right)$.

\section{Statistical analyses}

Intake, growth and nutrient uptake data were analysed using mixed model procedures of SAS [28]. The model included treatment, block, experimental run and sex. If effects of block, sex or experimental run were not significant $(P>0.05)$ and increased $P$-values, they were removed before final analysis. Blood-biochemical variables at $28 \mathrm{~d}$ were analysed using the same model but using 0 $\mathrm{d}$ data as covariates. Since CP intake could be a factor affecting serum amino acid concentrations, amino acids that were different at $P<0.10$ during initial analysis were additionally analysed using $\mathrm{CP}$ intake as covariate to test if these amino acid concentrations increased due to the $\mathrm{CP}$ intake or PBLC effects. Linear and quadratic effects of PBLC doses (0, 80 and $160 \mathrm{mg} / \mathrm{d})$ were assessed using polynomial contrasts. Contrasts between Control $(0 \mathrm{mg} /$ $\mathrm{d}$ of PBLC) versus both PBLC groups (80 and $160 \mathrm{mg} / \mathrm{d}$ of PBLC) were also used to determine the overall effects of PBLC compared with the Control. In addition, least significant difference (LSD) post hoc test was used to elucidate differences between PBLC-L or PBLC-H versus
Control. If outliers ( $>$ or $<$ median \pm 2.5 median absolute deviation) were detected [29], they were removed with a missing observation. Variability in the data was expressed as the pooled SEM, and statistical significance was set at $P \leq 0.05$, while a trend was considered at $0.05<P \leq 0.10$. Correlation between serum glucose concentrations and glucose uptakes in the rumen or intestine was determined using proc. corr of SAS [28].

\section{Results}

\section{Growth and nutrient intake}

Final BW as well as average daily gain of sheep was similar among treatments (Table 3). Supplementation of PBLC in diets tended to increase hay intake dosedependently $(P=0.090)$ so that hay intake tended to be higher for PBLC-L and PBLC-H each compared with Control $(P<0.10)$. Because all sheep consumed offered concentrates completely, this also resulted in a trend for linear increase $(P=0.091)$ in total feed intake that was reflected in a trend for higher feed intake when comparing PBLC-L or PBLC- $\mathrm{H}$ to Control individually $(P<$ $0.10)$. Crude protein intake also increased linearly $(P=$ $0.022)$ with a trend for increase when comparing Control versus PBLC-L $(P<0.10)$ and a significant increase when comparing Control versus PBLC-H $(P<0.05)$. Daily hay intake and total feed intake normalized per $\mathrm{kg}$ BW tended to be greater $(P<0.10)$ in PBLC groups when compared to Control individually and were greater $(P<0.05)$ when comparing both PBLC groups together to Control. Intake of NDF was not different among treatments, though it was numerically greater in the PBLC treatments.

Table 3 Effect of two doses of dietary menthol-rich plant bioactive lipid compounds (PBLC) on daily body weight (BW) gain and daily nutrient dry matter intake in sheep

\begin{tabular}{|c|c|c|c|c|c|c|c|}
\hline \multirow[t]{2}{*}{ Attribute } & \multicolumn{3}{|c|}{ Treatment ${ }^{\mathrm{a}, \mathrm{b}}$} & \multirow[t]{2}{*}{ SEM } & \multicolumn{3}{|c|}{ Contrast $^{c}$} \\
\hline & Control & PBLC-L & PBLC-H & & 1 & 2 & 3 \\
\hline Initial BW, kg ${ }^{\mathrm{C}}$ & 35.5 & 34.3 & 35.9 & 0.83 & 0.69 & 0.18 & 0.71 \\
\hline Final BW, kg & 39.1 & 38.4 & 39.7 & 0.63 & 0.47 & 0.43 & 0.84 \\
\hline Average daily BW gain, $\mathrm{g} / \mathrm{d}^{d}$ & 170 & 195 & 180 & 12.8 & 0.61 & 0.32 & 0.34 \\
\hline Hay intake, g/d & 660 & $707^{\#}$ & $725^{\#}$ & 25.6 & 0.090 & 0.65 & 0.091 \\
\hline Hay intake, g/(d · kg BW) & 17.6 & $19.1^{\#}$ & $19.0^{\#}$ & 0.55 & 0.091 & 0.25 & 0.047 \\
\hline Total feed intake, g/d & 1209 & $1255^{\#}$ & $1272^{\#}$ & 25.0 & 0.094 & 0.64 & 0.093 \\
\hline Total feed intake, $\mathrm{g} /(\mathrm{d} \cdot \mathrm{kg}$ BW) & 32.4 & $34.1^{\#}$ & $33.4^{\#}$ & 0.51 & 0.17 & 0.073 & 0.041 \\
\hline Crude protein intake, $\mathrm{g} / \mathrm{d}$ & 213 & $215^{\#}$ & $225^{*}$ & 3.58 & 0.022 & 0.40 & 0.096 \\
\hline NDF intake, $\mathrm{g} / \mathrm{d}$ & 532 & 552 & 578 & 19.5 & 0.12 & 0.77 & 0.13 \\
\hline
\end{tabular}

NDF: neutral detergent fibre; SEM: standard error of mean

${ }^{a}$ Control: without PBLC; PBLC-L: lower dose $(80 \mathrm{mg} / \mathrm{d})$ of PBLC; and PBLC-H: higher dose (160 mg/d) of PBLC

${ }^{\mathrm{b}}$ One outlier for average daily gain $(\mathrm{g} / \mathrm{d})<97$, hay intake $(\mathrm{g} / \mathrm{d})<525$, total feed intake $(\mathrm{g} / \mathrm{d})<1126$, and hay intake $(\mathrm{g} / \mathrm{kg}$ BW) $<15.3$ was removed for PBLC-L $(n=$ 7) before statistical analyses

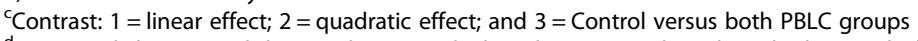

${ }^{d}$ Average daily gain and the initial BW to calculate this gain are based on the last $21 \mathrm{~d}$ of the study to nullify the effect of rumen fill during the first week that might have occurred due to changes in feed intake by PBLC

\#/*Mean values differ compared with the control at $P<0.10 / 0.05$ 
Table 4 Effect of two doses of dietary menthol-rich PBLC on different haematological values in sheep

\begin{tabular}{|c|c|c|c|c|c|c|c|}
\hline \multirow[t]{2}{*}{ Attribute } & \multicolumn{3}{|c|}{ Treatment ${ }^{\mathrm{a}, \mathrm{b}}$} & \multirow[t]{2}{*}{ SEM } & \multicolumn{3}{|c|}{ Contrast $^{c}$} \\
\hline & Control & PBLC-L & PBLC-H & & 1 & 2 & 3 \\
\hline \multicolumn{8}{|l|}{ Leucocyte profile } \\
\hline Total leucocytes, $\times 10^{9} / \mathrm{L}$ & 15.2 & 13.4 & 14.1 & 0.72 & 0.34 & 0.19 & 0.12 \\
\hline Lymphocyte, $\times 10^{9} / \mathrm{L}$ & 12.0 & 10.9 & 12.0 & 0.060 & 0.95 & 0.16 & 0.41 \\
\hline Lymphocyte, \% & 79.7 & $85.0^{* *}$ & $83.0^{*}$ & 1.09 & 0.044 & 0.020 & 0.006 \\
\hline Monocyte, $\times 10^{9} / \mathrm{L}$ & 0.074 & 0.068 & 0.072 & 0.0038 & 0.65 & 0.29 & 0.34 \\
\hline Monocyte, \% & 0.48 & 0.51 & 0.51 & 0.026 & 0.38 & 0.78 & 0.39 \\
\hline Neutrophil, $\times 10^{9} / \mathrm{L}$ & 2.96 & $2.26^{\#}$ & $2.18^{*}$ & 0.277 & 0.055 & 0.34 & 0.031 \\
\hline Neutrophil, \% & 19.8 & $14.4^{* *}$ & $16.5^{*}$ & 1.08 & 0.042 & 0.019 & 0.005 \\
\hline \multicolumn{8}{|l|}{ Erythrocyte profile } \\
\hline Total erythrocytes, $\times 10^{6} / \mathrm{L}$ & 15.0 & 14.6 & 14.7 & 0.46 & 0.66 & 0.65 & 0.54 \\
\hline Haemoglobin, g/dL & 12.5 & 12.2 & 12.5 & 0.38 & 0.94 & 0.53 & 0.70 \\
\hline$P C V, \%$ & 43.7 & 44.4 & 44.3 & 1.41 & 0.76 & 0.80 & 0.69 \\
\hline$M C V, f L$ & 23.1 & 23.9 & 23.4 & 0.64 & 0.79 & 0.44 & 0.53 \\
\hline $\mathrm{MCH}, \mathrm{pg}$ & 8.30 & 8.36 & 8.40 & 0.23 & 0.76 & 0.96 & 0.78 \\
\hline $\mathrm{MCHC}, \mathrm{g} / \mathrm{dL}$ & 35.8 & 35.2 & 36.0 & 0.70 & 0.89 & 0.42 & 0.70 \\
\hline RDWc, \% & 28.4 & 28.3 & 28.8 & 0.70 & 0.67 & 0.72 & 0.85 \\
\hline RDWs, fL & 24.7 & 25.0 & 25.1 & 0.62 & 0.66 & 0.90 & 0.66 \\
\hline \multicolumn{8}{|l|}{ Platelet profile } \\
\hline Platelets, $\times 10^{6} / \mathrm{L}$ & 368 & 372 & 389 & 61.3 & 0.81 & 0.93 & 0.87 \\
\hline$M P V, f L$ & 5.15 & 5.08 & 5.14 & 0.11 & 0.94 & 0.62 & 0.75 \\
\hline PCT, \% & 0.19 & 0.19 & 0.20 & 0.031 & 0.84 & 0.81 & 0.96 \\
\hline PDWc, \% & 21.6 & 21.2 & 21.7 & 0.55 & 0.95 & 0.52 & 0.79 \\
\hline PDWs, fL & 3.84 & 3.70 & 3.80 & 0.16 & 0.87 & 0.55 & 0.66 \\
\hline
\end{tabular}

$P C V$ packed cell volume, $M C V$ mean corpuscular volume, $M C H$ mean corpuscular haemoglobin, $M C H C$ mean corpuscular haemoglobin concentration, $R D W C$ red cell distribution width (co-efficient of variations), RDWs red cell distribution width (standard deviation), MPV mean platelet volume, PCT plateletcrit, $P D W C$ platelet distribution width (co-efficient of variations); and PDWs: platelet distribution width (standard deviation)

${ }^{a}$ Control: without PBLC; PBLC-L: lower dose $(133.3 \mathrm{mg} / \mathrm{kg})$ of PBLC; and PBLC-H: higher dose $(266.7 \mathrm{mg} / \mathrm{kg})$ of PBLC

${ }^{b}$ One outlier for lymphocyte $(\%)<70$ in PBLC-L $(n=7)$ and neutrophil $(\%)>29$ in PBLC-L $(n=7)$ and leucocyte number $>22.9 \times 10^{9} / L$ in PBLC-H $(n=7)$ was removed before analysis

'Contrast: 1 = linear effect; 2 = quadratic effect; and $3=$ Control versus both PBLC groups

$\# * * * * *$ Mean values differ compared with the control at $P<0.10 / 0.05 / 0.01$

\section{Blood haematological and biochemical profile}

Total leucocyte, lymphocyte and monocyte numbers were not different among treatments (Table 4). However, neutrophil counts tended to be lower for PBLC-L versus Control $(P<0.10)$ and were lower for PBLC-H versus Control $(P<0.05)$ or when comparing both PBLC groups versus Control $(P=0.031)$. This resulted in a quadratic decrease in proportion of neutrophils $(P=0.019)$ coupled to a quadratic increase in the proportion of lymphocytes $(P=0.020)$, which were also reflected in decreased proportion of neutrophils and increased proportions of lymphocytes when comparing PBLC-L or PBLC-H individually or jointly to Control $(P<0.05)$. The proportion of monocytes was unaffected by treatments. Various erythrocyte and platelet profiles were analysed, which were not influenced by treatments (Table 4).
Concentrations of glucose, bilirubin, triglycerides, cholesterol, urea and magnesium in serum were not different among sheep fed different doses of PBLC (Table 5). However, there was a trend for a linear increase in serum calcium concentrations due to PBLC feeding $(P=0.089)$, which was also reflected by a trend $(P<0.10)$ for increased serum calcium values for PBLC$\mathrm{H}$ versus Control .

The concentrations of free amino acids in serum were not changed $(P>0.10)$ except for Asp+Asn, Glu + Gln, Lys and, as a trend, Pro and Gly (Table 6). Concentrations of Asp+Asn $(P=0.005)$ and Glu + Gln $(P=0.041)$ increased linearly with increasing doses of PBLC and both were or tended to be different in comparisons of Control versus PBLC-L $(P<0.10$ for Asp+Asn; $P<0.05$ for $\mathrm{Glu}+\mathrm{Gln})$ or PBLC-H $(P<0.05$ for both). The difference between Control versus both PBLC groups was also 
Table 5 Effect of two doses of dietary menthol-rich PBLC on selected serum metabolites in sheep

\begin{tabular}{|c|c|c|c|c|c|c|c|}
\hline \multirow[t]{2}{*}{ Attribute } & \multicolumn{3}{|c|}{ Treatment $^{a}$} & \multirow[t]{2}{*}{ SEM } & \multicolumn{3}{|c|}{ Contrast $^{\mathrm{b}}$} \\
\hline & Control & PBLC-L & PBLC-H & & 1 & 2 & 3 \\
\hline Glucose, mmol/L & 4.04 & 3.95 & 3.98 & 0.065 & 0.49 & 0.43 & 0.32 \\
\hline Calcium, mmol/L & 2.62 & 2.62 & $2.68^{\#}$ & 0.022 & 0.089 & 0.41 & 0.26 \\
\hline Bilirubin, $\mu \mathrm{mol} / \mathrm{L}$ & 0.76 & 0.86 & 0.81 & 0.107 & 0.74 & 0.57 & 0.57 \\
\hline Tryglyceride, mmol/L & 0.23 & 0.22 & 0.24 & 0.022 & 0.81 & 0.63 & 0.98 \\
\hline Cholesterol, mmol/L & 1.60 & 1.65 & 1.64 & 0.044 & 0.53 & 0.44 & 0.41 \\
\hline Magnesium, mmol/L & 1.00 & 1.01 & 1.01 & 0.018 & 0.90 & 0.99 & 0.91 \\
\hline Urea, mmol/L & 9.38 & 10.1 & 9.61 & 0.382 & 0.67 & 0.21 & 0.32 \\
\hline
\end{tabular}

SEM standard error of mean

${ }^{a}$ Control: without PBLC; PBLC-L: lower dose $(80 \mathrm{mg} / \mathrm{d})$ of PBLC; and PBLC-H: higher dose $(160 \mathrm{mg} / \mathrm{d})$ of PBLC

${ }^{b}$ Contrast: 1 = linear effect; 2 = quadratic effect; and $3=$ Control versus both PBLC groups

\#Mean values differ compared with the control at $P<0.10$

significant for theses amino acids $(P=0.009$ and $P=$ 0.020 , respectively). The PBLC addition to the diet further tended to increase concentrations of Gly quadratically $(P=0.058)$ with a trend for higher concentrations for PBLC-L versus Control $(P<0.10)$ and Lys linearly

Table 6 The effect of menthol-rich PBLC on concentrations $(\mu \mathrm{mol} / \mathrm{L})$ of free amino acids in serum of sheep

\begin{tabular}{|c|c|c|c|c|c|c|c|}
\hline \multirow[t]{2}{*}{ Item } & \multicolumn{3}{|c|}{ Treatment $^{a}$} & \multirow[t]{2}{*}{ SEM } & \multicolumn{3}{|c|}{ Contrast $^{\mathrm{b}}$} \\
\hline & Control & PBLC-L & PBLC-H & & 1 & 2 & 3 \\
\hline Ala & 60 & 61 & 61 & 0.6 & 0.30 & 0.45 & 0.20 \\
\hline Val & 118 & 120 & 118 & 2.4 & 0.96 & 0.50 & 0.70 \\
\hline Leu & 133 & 137 & 137 & 1.8 & 0.14 & 0.49 & 0.11 \\
\hline lle & 133 & 136 & 136 & 1.3 & 0.19 & 0.46 & 0.14 \\
\hline Phe & 223 & 227 & 228 & 2.5 & 0.17 & 0.63 & 0.15 \\
\hline Met & 154 & 154 & 154 & 0.6 & 0.75 & 0.92 & 0.82 \\
\hline $\operatorname{Pro}^{c}$ & 103 & $105^{\#}$ & 105 & 1.0 & 0.12 & 0.32 & 0.072 \\
\hline Gly ${ }^{c}$ & 60 & $66^{\#}$ & 59 & 2.5 & 0.85 & 0.058 & 0.41 \\
\hline Ser & 82 & 82 & 84 & 1.7 & 0.42 & 0.72 & 0.60 \\
\hline Cys & 200 & 200 & 201 & 0.7 & 0.13 & 0.39 & 0.37 \\
\hline Thr & 113 & 115 & 115 & 1.2 & 0.30 & 0.50 & 0.22 \\
\hline Tyr & 289 & 298 & 290 & 4.3 & 0.84 & 0.11 & 0.32 \\
\hline$A s p+A s n^{c}$ & 121 & $125^{\#}$ & $128^{*}$ & 1.4 & 0.005 & 0.79 & 0.009 \\
\hline $\mathrm{Glu}+\mathrm{G} \ln { }^{c}$ & 160 & $174^{*}$ & $174^{*}$ & 4.5 & 0.041 & 0.22 & 0.020 \\
\hline Lys $^{c}$ & 147 & 148 & $152^{*}$ & 1.5 & 0.054 & 0.50 & 0.17 \\
\hline His & 171 & 171 & 168 & 1.9 & 0.31 & 0.62 & 0.52 \\
\hline Arg & 345 & 353 & 341 & 11.9 & 0.81 & 0.41 & 0.83 \\
\hline Total & 2611 & 2672 & 2651 & 32.0 & 0.42 & 0.52 & 0.68 \\
\hline
\end{tabular}

SEM standard error of mean

${ }^{a}$ Control: without PBLC; PBLC-L: lower dose $(80 \mathrm{mg} / \mathrm{d})$ of PBLC; and PBLC-H: higher dose $(160 \mathrm{mg} / \mathrm{d})$ of PBLC

${ }^{\mathrm{b}}$ Contrast: 1 = linear effect; 2 = quadratic effect; and $3=$ Control versus both PBLC groups

'Since CP intake could be a factor affecting serum amino acid concentrations, $\mathrm{CP}$ intake was used as covariate for amino acids those resulted in $P<0.10$, and the statistical results are provided in the text

\#/* Mean values differ compared with the control at $P<0.10 / 0.05$
$(P=0.072)$ with higher concentrations for PBLC-H versus Control $(P<0.05)$. Finally, serum concentrations of Pro tended to be increased when comparing PBLC-L to Control $(P<0.10)$ or when comparing both PBLC groups to Control $(P=0.054)$. When $\mathrm{CP}$ intake was used as a covariate, concentrations of Asp+Asn (linear effect, $P=0.034$; Control versus both PBLC, $P=0.041)$, Glu + Gln (Control versus PBLC, $P=0.041$ ) and Gly (quadratic effect, $P=0.071$ ) were or tended to be increased by PBLC. However, Pro and Lys concentrations were not altered $(P>0.10)$.

\section{Electrophysiology and uptakes of glucose and methionine in gastrointestinal epithelia}

Pre-feeding of PBLC increased $I_{\mathrm{sc}}$ linearly in ruminal epithelia $(P<0.001)$ and also tended to increase $I_{\mathrm{sc}}$ linearly in intestinal epithelia $(P=0.085$; Table 7$) . I_{\mathrm{sc}}$ values were higher in PBLC groups when tested either individually or jointly against Control in ruminal epithelia $(P<0.01)$ and tended to be higher when comparing PBLC-H or both PBLC groups with Control in intestinal epithelia $(P<0.10)$. Baseline $G_{t}$ increased linearly with increasing doses of PBLC in the rumen $(P=0.013)$ based on greater values for PBLC-L $(P<0.05)$ or PBLC-H $(P<$ $0.01)$ versus Control; however, $G_{\mathrm{t}}$ was not altered in the jejunum (Table 7).

Ruminal uptakes of glucose and methionine were not affected by the dietary PBLC in the presence of $\mathrm{Na}^{+}$. In the absence of $\mathrm{Na}^{+}$, however, uptake of glucose tended to increase linearly $(P=0.053)$ and methionine uptake increased linearly $(P=0.036)$, which was based on higher uptakes of glucose and methionine in PBLC-H compared with Control $(P<0.05)$. In the jejunum, uptakes of glucose and methionine were not influenced by PBLC in the presence or absence of $\mathrm{Na}^{+}$.

Across treatments, the absence of $\mathrm{Na}^{+}$tended to decrease the ruminal uptake of glucose [from 250 to 211 $\left.\mathrm{pmol} /\left(\mathrm{cm}^{2} \cdot \mathrm{min}\right) ; \mathrm{SE}=17.1 ; P=0.089\right]$, but not of 
Table 7 Effect of two doses of dietary menthol-rich PBLC on ruminal and jejunal short-circuit current $\left[I_{s c i} \mu \mathrm{Eq} /\left(\mathrm{cm}^{2} \cdot h\right)\right]$, conductance $\left(G_{t} ; \mathrm{mS} / \mathrm{cm}^{2}\right)$ and uptakes $\left[\mathrm{pmol} /\left(\mathrm{cm}^{2} \cdot \mathrm{min}\right)\right]$ of glucose $\left(U_{\text {gluc }}\right)$ and methionine $\left(U_{\text {met }}\right)$ in the presence $\left(+\mathrm{Na}^{+}\right)$or absence of $\mathrm{Na}^{+}\left(-\mathrm{Na}^{+}\right)$

\begin{tabular}{|c|c|c|c|c|c|c|c|}
\hline \multirow[t]{2}{*}{ Attribute } & \multicolumn{3}{|c|}{ Treatment ${ }^{a, b}$} & \multirow[t]{2}{*}{ SEM } & \multicolumn{3}{|c|}{ Contrast $^{c}$} \\
\hline & Control & PBLC-L & PBLC-H & & 1 & 2 & 3 \\
\hline \multicolumn{8}{|l|}{ Rumen } \\
\hline $\mathrm{I}_{\mathrm{SC}}\left(+\mathrm{Na}^{+}\right)$ & 10.8 & $21.8^{* *}$ & $20.6^{* *}$ & 1.46 & $<0.001$ & 0.004 & $<0.001$ \\
\hline $\mathrm{G}_{\mathrm{t}}\left(+\mathrm{Na}^{+}\right)$ & 3.38 & $3.62^{*}$ & $4.40^{* *}$ & 0.26 & 0.013 & 0.41 & 0.065 \\
\hline$U_{\text {gluc }}\left(+\mathrm{Na}^{+}\right)$ & 237 & 251 & 274 & 36.6 & 0.48 & 0.92 & 0.57 \\
\hline$U_{\text {gluc }}\left(-\mathrm{Na}^{+}\right)$ & 203 & 194 & $255^{*}$ & 17.5 & 0.053 & 0.12 & 0.33 \\
\hline$U_{\text {met }}\left(+\mathrm{Na}^{+}\right)$ & 56.2 & 60.8 & 71.2 & 11.3 & 0.36 & 0.84 & 0.49 \\
\hline$U_{\text {met }}\left(-\mathrm{Na}^{+}\right)$ & 50.3 & 45.7 & $67.9^{*}$ & 5.48 & 0.036 & 0.061 & 0.35 \\
\hline \multicolumn{8}{|l|}{ Jejunum } \\
\hline$I_{\mathrm{SC}}\left(+\mathrm{Na}^{+}\right)$ & 5.27 & 9.40 & $9.91^{\#}$ & 1.81 & 0.085 & 0.43 & 0.063 \\
\hline $\mathrm{G}_{\mathrm{t}}\left(+\mathrm{Na}^{+}\right)$ & 28.9 & 26.6 & 27.7 & 1.96 & 0.66 & 0.49 & 0.47 \\
\hline$U_{\text {gluc }}\left(+\mathrm{Na}^{+}\right)$ & 1239 & 1465 & 1145 & 151 & 0.66 & 0.16 & 0.73 \\
\hline$U_{\text {gluc }}\left(-\mathrm{Na}^{+}\right)$ & 842 & 893 & 746 & 127 & 0.60 & 0.53 & 0.89 \\
\hline$U_{\text {met }}\left(+\mathrm{Na}^{+}\right)$ & 715 & 817 & 603 & 94.0 & 0.40 & 0.18 & 0.97 \\
\hline$U_{\text {met }}\left(-\mathrm{Na}^{+}\right)$ & 376 & 463 & 365 & 55.3 & 0.89 & 0.19 & 0.59 \\
\hline
\end{tabular}

SEM standard error of mean

${ }^{a}$ Control: without PBLC; PBLC-L: lower dose $(80 \mathrm{mg} / \mathrm{d})$ of PBLC; and PBLC-H: higher dose $(160 \mathrm{mg} / \mathrm{d})$ of PBLC

${ }^{b}$ One animal in each treatment was removed due to high conductivity

${ }^{c}$ Contrast: 1 = linear effect; 2 = quadratic effect; and $3=$ Control versus both PBLC groups

$\# / * / * *$ Mean values differ compared with the control at $P<0.10 / 0.05 / 0.01$

methionine $\left[62.2\right.$ versus $51.1 \mathrm{pmol} /\left(\mathrm{cm}^{2} \cdot \min \right) ; \mathrm{SE}=$ 5.33; $P=0.23]$. Intestinal uptakes of glucose $[1,283$ versus $\left.827 \mathrm{pmol} /\left(\mathrm{cm}^{2} \cdot \mathrm{min}\right) ; \mathrm{SE}=82.4 ; P<0.001\right]$ and $\mathrm{me}-$ thionine [727 versus $421 \mathrm{pmol} /\left(\mathrm{cm}^{2} \cdot \mathrm{min}\right) ; \mathrm{SE}=46.2$; $P<0.001$ ] greatly differed in the presence versus absence of $\mathrm{Na}^{+}$. Overall, uptakes were about 5 and 10 times greater for glucose and methionine, respectively, in the intestine than in the rumen. A positive correlation $(r=$ $0.44 ; P=0.044$ ) was discovered between ruminal glucose uptakes in the presence of $\mathrm{Na}^{+}$and serum glucose concentrations (Fig. 1). However, no such correlation was noted between intestinal glucose uptakes and serum glucose concentrations.

\section{Discussion}

Hay intake and consequently total feed intake increased due to PBLC addition to the diet. Menthol has characteristic gustatory and olfactory stimulating effects that
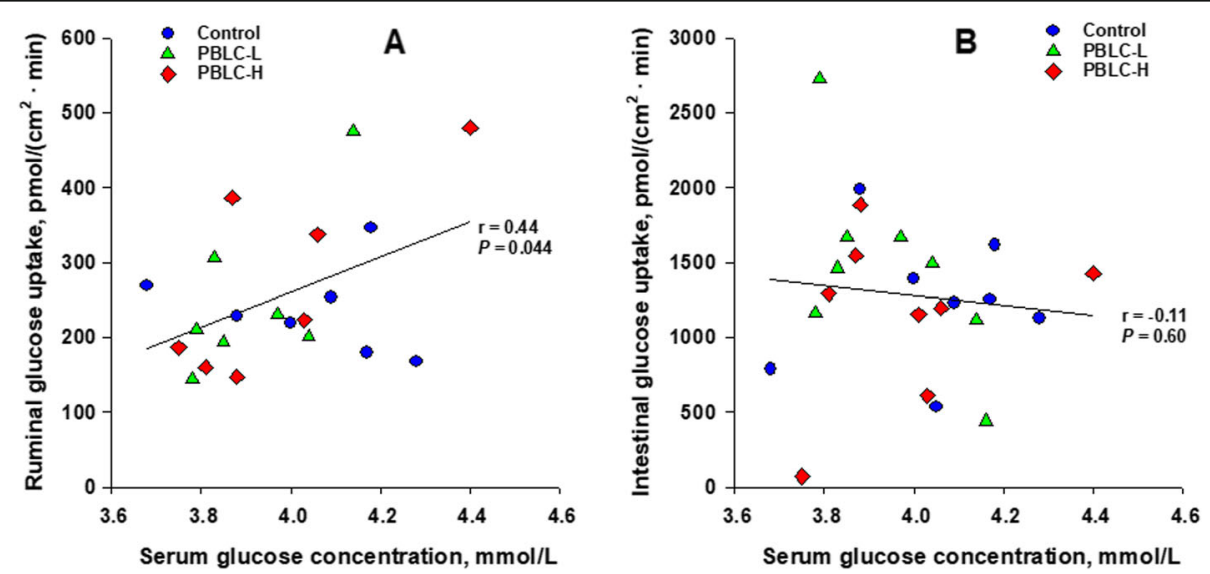

Fig. 1 Correlations between serum glucose concentrations and ruminal glucose uptakes (a) or intestinal glucose uptakes (b) in the presence of $\mathrm{Na}^{+}$in sheep. Control: without PBLC; PBLC-L: lower dose $(80 \mathrm{mg} / \mathrm{d})$ of PBLC; and PBLC-H: higher dose (160 mg/d) of PBLC 
may affect feed intake and eating behaviour of sheep [30]. In a previous study where crystalline menthol (0, 30,300 and $3,000 \mathrm{mg} / \mathrm{kg}$ diet) was supplemented to steers, overall DM intake was not affected by treatments, but was influenced by an interaction between treatment $x$ day. Steers consumed less feed when supplemented with the highest dose of $3,000 \mathrm{mg} / \mathrm{kg}$ diet of menthol from d 5 through 12, but DM intake was similar among treatments after day 13 [31]. In the present study, we wanted to avoid any depression of feed intake and used two doses of PBLC in the lower range of that previous study (80 to $160 \mathrm{mg} / \mathrm{d}$; equivalent to a menthol dose of 57 to $114 \mathrm{mg} / \mathrm{kg}$ diet DM). Those low doses appeared to stimulate appetite, resulting in higher hay and total feed intake per unit of BW. Intake of CP increased linearly in parallel, whereas NDF intake was only numerically higher for the PBLC treatments. The latter was attributable to numerically higher concentrations of NDF in the orts samples for the PBLC treatments. We recently identified that the observed stimulation of appetite by lowdose menthol extended beyond the periods when the menthol-rich concentrates are provided, i.e., it was also evident for hay consumption between concentrate feeding hours [32].

Feeding of other PBLC resulted in inconsistent effects on feed intake in different studies. In agreement with our study, clove or cinnamon oil ( 3.5 and $7 \mathrm{~g} / \mathrm{d}$ in bulls) [9], rosemary oil $(0.5 \mathrm{~g} / \mathrm{kg}$ concentrate in sheep) [33] and cinnamaldehyde (0.4 to $1.6 \mathrm{~g} / \mathrm{d}$ in steers) [34] increased feed intake. Some studies reported no effect on feed intake $(0.5$ and $10 \mathrm{~g} / \mathrm{d}$ of a mixture of cinnamaldehyde and eugenol, and $0.25 \mathrm{~g} / \mathrm{d}$ of capsicum oil in lactating Holstein cows [35]; copaiba oil at 0.5 to $1.5 \mathrm{~g} / \mathrm{kg} \mathrm{DM}$ in sheep [36]; $110 \mathrm{mg} / \mathrm{d}$ of peppermint oil in sheep [37]); whereas few studies reported lower feed intake (PBLC mixture containing as main components thymol, eugenol, vanillin, and limonene at $1.2 \mathrm{~g} / \mathrm{d}$ in lactating dairy cows [38]). The variable effects on feed intake in different studies might be due to the fact that type and concentrations of applied PBLC differed strongly between experiments.

The higher feed intake per kg BW was not correlated with higher average daily weight gain in the present study. This might be due to the relatively short duration of the study where small increases in daily weight gain may be difficult to identify. Another possibility could be that PBLC decreased digestibility. Because SCFA concentrations were not altered; however, it is rather unlikely that PBLC impacted on daily BW changes via decreased diet digestibility. Alternatively, menthol has been shown to increase TRP-M (melastatin) channelmediated brown fat thermogenesis and metabolic rate in humans $[39,40]$. In lactating dairy cows, dietary addition of peppermint herb (Mentha piperita; $50 \mathrm{~g} / \mathrm{kg}$ diet) with menthol as the main PBLC similarly increased heat production [41]. The increased energy expenditure and heat production during menthol supplementation possibly originates from chemically induced cold sensation because menthol is a well-described agonist of the TRPM8 channel that functions as a cold receptor [42]. This might partly explain the missing effect on body weight gain despite higher feed intakes in mentholsupplemented animals. Similar to our study, no effect on BW gain was observed after addition of crystalline menthol to diets of steers [31] or after supplementing menthol-containing PBLC blends to growing lambs [4] or calves [43].

Supplementation of PBLC at $80-160 \mathrm{mg} / \mathrm{d}$ to the diets did not alter blood biochemical profile in the present study, except for a trend for increased serum calcium levels in the PBLC-H group $(160 \mathrm{mg} / \mathrm{d})$. In previous studies, changes of blood biochemical profiles due to dietary PBLC were occasionally observed and primarily affected the lipid profile [7, 44, 45]. Serum calcium concentrations were rarely monitored in those studies. We had included the measurement of calcium and magnesium in our protocol since it has been shown recently that menthol and some other PBLC can activate TRP channels in the gastrointestinal tract [16, 17]. These channels play a role in cation absorption with special importance for divalent cations. Accordingly, a recent study had already shown significant increases in serum calcium levels of dairy cows after supplementing a menthol-rich PBLC similar to that of the present study [46]. Although the increase in serum calcium was not significant in the present study, it points into the same direction that menthol-rich PBLC can support calcium homeostasis of ruminants, most likely, by stimulating calcium absorption from the gastrointestinal tract.

Concentrations of selected amino acids in serum were increased by menthol-rich PBLC, which could possibly be due to increased $\mathrm{CP}$ intake [47] considering the increased $\mathrm{CP}$ intake during PBLC feeding in the present study. However, the selectively increased concentrations of Glu + Gln and Asp+Asn, especially at the higher dose $(160 \mathrm{mg} / \mathrm{d})$, were independent (using CP intake as a covariate) of $\mathrm{CP}$ intake, which strongly suggests that $\mathrm{PBLC}$ was causative for this response. As just elaborated for calcium, menthol has been shown to activate TRP channels in the gastrointestinal tract which, in the rumen, leads to increased $\mathrm{NH}_{4}{ }^{+}$absorption [16, 17]. Increased absorption of $\mathrm{NH}_{4}{ }^{+}$requires increased Gln synthesis via hepatic glutamine synthetase activity. Subsequently, Glu and Gln are important substrates for the synthesis of Asp from oxaloacetate by aspartate aminotransferase enzyme and Asn from Asp by asparagine synthetase, respectively [48]. These biochemical conversions may plausibly explain the selective increase in precursor 
amino acids for the urea cycle (Glu, Gln, Asp) despite the fact that plasma urea concentration was not measurably altered. In a recent study with dairy cows, a similar source of menthol-rich PBLC even decreased blood and milk urea levels whereas milk protein yield increased [46]. The latter suggests that increased synthesis of ureagenic amino acids may potentially contribute to improved protein efficiency.

There is relatively little information regarding the effects of menthol or other PBLC on the haematogram in ruminants. A PBLC mixture (ricinoleic and anacardic acid, cardanol and cardol) fed to bulls $(0.42 \mathrm{~g} / \mathrm{kg} \mathrm{DM})$ did not change any haemato-biochemical variables [49]. In rams, feeding of Mentha piperita-treated silage (20 $\mathrm{mL} / \mathrm{kg}$ diet) increased WBC count, but had no effect on $\mathrm{RBC}$ numbers [50]. In the present study, haematological values were within the reported reference ranges for sheep $[51,52]$ and were not affected by treatment except for neutrophil count, which decreased linearly with increasing PBLC dose. We are not aware of any previous study showing an effect of menthol or other PBLC on blood neutrophil counts. However, few studies reported that certain PBLC suppressed neutrophil migration and accumulation in inflammatory sites [53-55]. Moreover, an oral administration of menthol reduced neutrophil counts in rats' stomach suffering from ethanol-induced gastritis [56] and reduced the production of different inflammatory mediators $[57,58]$. These observations support the view that the reduced neutrophil count in the present study may suggest a decreased inflammatory status and thus improved health resilience of sheep supplemented with menthol-rich PBLC.

One last intention of the present study was to investigate the effects of PBLC on the function of ruminal and jejunal epithelia with special focus on nutrient uptake. The results first confirmed the general textbook knowledge that the small intestine is the main site of glucose and amino acid absorption in ruminants. In the jejunum, uptakes of glucose and methionine were clearly dependent on the presence of $\mathrm{Na}^{+}$, which implies that $\mathrm{Na}^{+}$-dependent transporters have a significant contribution to the transport of these nutrients in the small intestine. Uptake of methionine from the rumen was negligible and not clearly $\mathrm{Na}^{+}$-dependent, which suggest that rumen has no quantitative significance for the absorption of methionine and likely also other amino acid. Ruminal glucose uptake tended to be greater in the presence versus the absence of $\mathrm{Na}^{+}$. This confirmed results of previous studies demonstrating $\mathrm{Na}^{+}$-dependent absorption of glucose from the rumen $[26,27,59]$. Furthermore, the present study identified, for the first time, a positive correlation between blood glucose concentration and ruminal glucose uptake. This is remarkable and supports the functional relevance of a previously postulated sugar-sensing mechanism on the basolateral side of ruminal epithelia. An earlier study had shown that serosal pre-incubation with $D$-glucose, $D$-mannose, 3-Omethyl- $D$-glucose or sucrose can up-regulate apical glucose uptake of isolated ruminal epithelia via such sensor [60]. It was speculated in that previous publication that the functional relevance of this mechanism is to adapt ruminal glucose absorption to the supply of easily fermentable carbohydrates, especially sugars, to the rumen because increased sugar supply to the rumen can effectively trigger an increase in blood glucose [60]. This is different from the intestine of sheep where upregulation of glucose absorption is also triggered by an increased supply of sugars but the sensor is luminal [61-63].

Despite the absence of data on menthol, we had speculated about an influence of menthol-rich PBLC on apical glucose or methionine uptake based on previous publications showing either stimulatory (thymol and carvacrol mixture [64] or cinnamaldehyde [14]) or inhibitory effects (trans-resveratrol and $\varepsilon$-viniferin [19] or quercetin-3-O-glucoside [18]) of certain other secondary plant metabolites on nutrient uptake. Our results showed that apical glucose and methionine uptakes in ruminal epithelia were not influenced by PBLC under $\mathrm{Na}^{+}$-containing conditions, which suggests that $\mathrm{Na}^{+}-$ dependent glucose cotransporters (e.g., SGLT1 [26, 27, 65]) or $\mathrm{Na}^{+}$-dependent methionine transporters (e.g., $\mathrm{B}^{0} \mathrm{AT} 1, \mathrm{ATB}^{0}+$, IMINO and ASCT2 [66]) were not affected by pre-feeding menthol-rich PBLC. However, $\mathrm{Na}^{+}$-independent ruminal uptakes of both glucose and methionine increased in PBLC pre-fed sheep at the higher dose $(160 \mathrm{mg} / \mathrm{d})$. Increased uptakes of glucose and methionine from the ruminal epithelia in the absence of $\mathrm{Na}^{+}$may involve $\mathrm{Na}^{+}$-independent transport facilitators (e.g., GLUT-2 and GLUT-5 for glucose, and $\mathrm{b}^{0} \mathrm{AT}$ for methionine [27,65-67]), which could potentially be stimulated by PBLC. Alternatively, this may indicate an upregulation of a more general unspecific pathway of passive substrate uptake like the paracellular route.

Another indication for an opening of the paracellular space in the rumen may be taken from the increase of $G_{\mathrm{t}}$ following supplementation with menthol-rich PBLC, which was restricted to the rumen but not the jejunum. The paracellular space is an unspecific pathway for passive ion permeation and thus contributes significantly to $G_{\mathrm{t}}$ [68]. The paracellular space is much tighter in the rumen than the jejunum [68]; thus even small increases in paracellular permeability are readily accompanied by increases in $G_{\mathrm{t}}$ [69]. Alternatively, increases in $G_{\mathrm{t}}$ may also point to an opening of ion channel conductivities, especially, if they concur with increases in $I_{\mathrm{sc}}$. An increase of $I_{\mathrm{sc}}$ was observed in the rumen and, as a trend, in the small intestine of the PBLC-supplemented sheep 
and reflects either enforced transcellular cation absorption or enforced transcellular anion secretion. Menthol is a potent activator of TRPM8 and TRPV3, the latter being involved in cation absorption across gastrointestinal epithelia. The ruminal epithelium contains several TRP channels, including TRPV3. The addition of menthol to isolated ruminal epithelium ex vivo has been shown to lead to parallel increases of $I_{\mathrm{sc}}$ and $G_{\mathrm{t}}$, which were electrophysiological correlates of increased absorptive fluxes of cations like calcium and ammonium in previous studies $[16,17]$.

Viewing all findings of the present study synoptically, it appears that addition of menthol-rich PBLC in the tested dose range offers several beneficial effects. The majority of findings were based on linear effects or trends for linear effects with a more prominent appearance in PBLC-H. This indicates that increasing benefits are possible with increasing doses up to a total dose of $114 \mathrm{mg}$ menthol per $\mathrm{kg}$ DMI. The latter appears to be a rather low dose compared to many literature studies. When assessing the dose holistically, however, safety has to be considered as well. In the EU, for example, menthol supplementation is judged unrestrictedly safe up to a concentration of $25 \mathrm{mg} / \mathrm{kg}$ complete feeding stuff. Exceeding this concentration is possible but requires detailed labelling [70].

\section{Conclusions}

The present study revealed a potential for use of menthol-rich PBLC in growing sheep in doses up to $100 \mathrm{mg} / \mathrm{kg}$ DMI. The applied PBLC improved feed intake but had no measurable short-term effect on growth. Linear decreases in neutrophil count and a trend for linear increases in serum calcium levels after PBLC addition could point to attenuation of inflammatory reactions and positive effects on calcium homeostasis, respectively, when considering other literature findings. An activation of TRP channels in the gastrointestinal tract by menthol could jointly explain the observed trend for higher serum calcium levels (via increased calcium absorption) and the selective linear increase in urea precursor amino acids in blood serum of PBLCsupplemented sheep (via increased ruminal absorption of $\mathrm{NH}_{4}^{+}$). Further analysis of ruminal and jejunal functions ex vivo revealed increased $\mathrm{Na}^{+}$-independent uptakes of glucose and methionine and increased ion currents and permeability in the rumen especially at the higher dose of PBLC supplementation. These altered epithelial functions may indicate either an opening of a common unspecific transport pathway, e.g. the paracellular space, and/or coordinated upregulation of several selective transport and permeation pathways, again, including TRP channels.

\section{Abbreviations}

$A D F_{o m}$ : Acid detergent fibre expressed exclusive of ash; $C P$ : Crude protein; DM: Dry matter; DMI: Dry matter intake; EE: Ether extract; $G_{t}$ : Tissue conductance; $I_{\text {sc: }}$ Short-circuit current; MCH: Mean corpuscular haemoglobin; MCHC: Mean corpuscular haemoglobin concentration; MCV: Mean corpuscular volume; MPV: Mean platelet volume; NDF om: Neutral detergent fibre expressed exclusive of ash; OM: Organic matter; PBLC: Plant bioactive lipid compounds; PBLC-H: PBLC at a higher dose $(160 \mathrm{mg} / \mathrm{d})$; PBLC-L: PBLC at a lower dose $(80 \mathrm{mg} / \mathrm{d})$; PCT: Plateletcrit; PCV: Packed cell volume;

$P D_{\mathrm{t}}$ : Potential difference; PDWc: Platelet distribution width (co-efficient of variations); PDWs: Platelet distribution width (standard deviation); RDWc: Red cell distribution width (co-efficient of variations); RDWs: Red cell distribution width (standard deviation); SCFA: Short-chain fatty acid; TRP: Transient receptor potential

\section{Acknowledgements}

We gratefully acknowledge the support by the barn staff of the animal facility. We further thank G. Köller and his team (Leipzig University, Leipzig, Germany) for their support in analysing the blood samples. The help of Paulina Szulc (Poznan University of Life Sciences, Poznan, Poland) in sample processing and preparation of amino acid data is highly appreciated.

\section{Authors' contributions}

AKP, SG, KTS, HSB and JRA designed and conducted the experiment. AKP and RP designed the feeding. $\mathrm{HG}$ and AS took responsibility for the blood haematological and biochemical analyses, respectively. AC and MSS contributed to the idea, determination and method description of amino acid analysis. AKP analysed all final data sets and created figures and tables. AKP wrote the manuscript together with JRA. All authors reviewed and approved the final version of the manuscript. AKP and JRA obtained funding for this study.

\section{Funding}

This work was supported by a fellowship from the Alexander von Humboldt Foundation to AKP and accessory bench fees. The study received further financial support from PerformaNat $\mathrm{GmbH}$. Amino acid analysis was supported by the framework of the Ministry of Science and Higher Education programme as "Regional Initiative Excellence" in years 2019-2022, Project No. 005/RID/2018/19 (by AC and MSS).

\section{Availability of data and materials}

All data that support the findings of this study are included in this published article.

\section{Ethics approval and consent to participate}

This study was performed in accordance with the German ethical and anima care legislation and approved by the State Office of Health and Social Affairs 'Landesamt für Gesundheit und Soziales Berlin' (Reference number, G0141/ 17).

\section{Consent for publication}

Not applicable.

\section{Competing interests}

KTS and HSB are employees of PerformaNat GmbH, Germany, which funded parts of the study. This fact had no influence on the interpretation of results and does not affect authors' adherence to the policies of the Journal of Animal Science and Biotechnology on sharing data and materials. All other authors declare no competing interests.

\section{Author details}

${ }^{1}$ Institute of Veterinary Physiology, Freie Universität Berlin, Oertzenweg 19b, 14163 Berlin, Germany. ${ }^{2}$ Department of Animal Nutrition, West Bengal University of Animal and Fishery Sciences, 37 K. B. Sarani, Kolkata 700037, India. ${ }^{3}$ PerformaNat GmbH, Hohentwielsteig 6, 14163 Berlin, Germany. ${ }^{4}$ Equine Clinic: Surgery and Radiology, Freie Universität Berlin, Oertzenweg 19b, 14163 Berlin, Germany. ${ }^{5}$ Clinic for Ruminants and Swine, Faculty of Veterinary Medicine, University of Leipzig, An den Tierkliniken 11, 04103 Leipzig, Germany. ${ }^{6}$ Institute of Animal Nutrition, Freie Universität Berlin, Königin-Luise-Strasse 49, 14195 Berlin, Germany. ${ }^{7}$ Department of Animal 
Nutrition, Poznan University of Life Sciences, Wolynska 33, 60-637 Poznan Poland.

\section{Received: 27 May 2019 Accepted: 10 October 2019} Published online: 02 December 2019

\section{References}

1. Dibner JJ, Richards JD. Antibiotic growth promoters in agriculture: history and mode of action. Poult Sci. 2005;84:634-43.

2. Brown K, Uwiera RRE, Kalmokoff ML, Brooks SPJ, Inglis GD. Antimicrobial growth promoter use in livestock: a requirement to understand their modes of action to develop effective alternatives. Int J Antimicrob Agents. 2017;49: $12-24$.

3. Brown G, Ducatelle R, Van Immerseel F. An update on alternatives to antimicrobial growth promoters for broilers. Vet J. 2011;187:182-8.

4. Mirzaei-Alamouti H, Moradi S, Shahalizadeh Z, Razavian M, Amanlou H, Harkinezhad T, et al. Both monensin and plant extract alter ruminal fermentation in sheep but only monensin affects the expression of genes involved in acid-base transport of the ruminal epithelium. Anim Feed Sci Technol. 2016:219:132-43.

5. Blanch M, Carro MD, Ranilla MJ, Viso A, Vázquez-Anón M, Bach A. Influence of a mixture of cinnamaldehyde and garlic oil on rumen fermentation, feeding behavior and performance of lactating dairy cows. Anim Feed Sci Technol. 2016;219:313-23.

6. Atanasov AG, Waltenberger B, Pferschy-Wenzig EM, Linder T, Wawrosch C, Uhrin $\mathrm{P}$, et al. Discovery and resupply of pharmacologically active plantderived natural products: a review. Biotechnol Adv. 2015;33:1582-614.

7. Patra AK, Saxena J. A new perspective on the use of plant secondary metabolites to inhibit methanogenesis in the rumen. Phytochemistry. 2010; 71:1198-222.

8. Chowdhury S, Mandal GP, Patra AK, Samanta I, Pradhan S, Kumar P, et al Different essential oils in diets of broiler chickens: 2. Gut microbes and morphology, immune response, and some blood profile and antioxidant enzymes. Anim Feed Sci Technol. 2018;236:39-47.

9. Ornaghi MG, Passetti RAC, Torrecilhas JA, Mottin C, Prado IN. Essential oils in the diet of young bulls: effect on animal performance, digestibility, temperament, feeding behaviour and carcass characteristics. Anim Feed Sci Technol. 2017;234:274-83.

10. Patra AK. Effects of essential oils on rumen fermentation, microbial ecology and ruminant production. Asian J Anim Vet Adv. 2011;6:416-28.

11. Patra AK, Amasheh $S$, Aschenbach JR. Modulation of gastrointestinal barrier and nutrient transport function in farm animals by natural plant bioactive compounds - a comprehensive review. Crit Rev Food Sci Nutr. 2018. https:// doi.org/10.1080/10408398.2018.1486284.

12. Zou Y, Xiang Q, Wang J, Peng J, Wei H. Oregano essential oil improves intestinal morphology and expression of tight junction proteins associated with modulation of selected intestinal bacteria and immune status in a pig model. Biomed Res Int. 2016:2016:5436738.

13. Liehr M, Mereu A, Pastor JJ, Quintela JC, Staats S, Rimbach G, et al. Olive oil bioactives protect pigs against experimentally-induced chronic inflammation independently of alterations in gut microbiota. PLoS One. 2017:12:e0174239.

14. Williams AR, Hansen TVA, Krych L, Ahmad HFB, Nielsen DS, Skovgaard K, et al. Dietary cinnamaldehyde enhances acquisition of specific antibodies following helminth infection in pigs. Vet Immunol Immunopathol. 2017;189: 43-52.

15. Liu Y, Song M, Che TM, Lee JJ, Bravo D, Maddox CW, et al. Dietary plant extracts modulate gene expression profiles in ileal mucosa of weaned pigs after an Escherichia coli infection. J Anim Sci. 2014:92:2050-62.

16. Rosendahl J, Braun HS, Schrapers KT, Martens H, Stumpff F. Evidence for the functional involvement of members of the TRP channel family in the uptake of $\mathrm{Na}^{+}$and $\mathrm{NH}_{4}^{+}$by the ruminal epithelium. Pflugers Arch. 2016;468:1333-52.

17. Schrapers KT, Sponder G, Liebe F, Liebe H, Stumpff F. The bovine TRPV3 as a pathway for the uptake of $\mathrm{Na}^{+}, \mathrm{Ca}^{2+}$ and $\mathrm{NH}_{4}^{+}$. PLoS One. 2018;13: e0193519.

18. Cermak R, Landgraf S, Wolffram S. Quercetin glucosides inhibit glucose uptake into brush-border-membrane vesicles of porcine jejunum. Br J Nutr. 2004:91:849-55.

19. Guschlbauer M, Klinger S, Burmester M, Horn J, Kulling SE, Breves G. transresveratrol and $\varepsilon$-viniferin decrease glucose absorption in porcine jejunum and ileum in vitro. Comp. Biochem Physiol A Mol Integr Physiol. 2013;165:313-8.
20. Ando S, Nishida T, Ishida M, Hosoda K, Bayaru E. Effect of peppermint feeding on the digestibility, ruminal fermentation and protozoa. Livest Prod Sci. 2003;82:245-8.

21. Patra AK, Yu Z. Effects of essential oils on methane production and fermentation by, and abundance and diversity of, rumen microbial populations. Appl Environ Microbiol. 2012;78:4271-80.

22. McKay DL, Blumberg JB. A review of the bioactivity and potential health benefits of peppermint tea (Mentha piperita L.). Phytother Res. 2006;20:619-33.

23. NRC. Nutrient requirements of small ruminants: sheep, goats, cervids, and new world camelids. Washington, DC: National Research Council, The National Academies Press; 2007.

24. Waters Corporation UPLC Amino Acid Analysis Solution Revision B: System Guide, 2007:67-76.

25. Naumann K, Bassler R, Seibold R, Barth K. Die Chemische Untersuchung Von Futtermitteln. Lose Blattausgabe Mit Ergänzungen 1983, 1988, 1993, 1997 und 2004, Methodenbuch, 'chemical analysis of feed stuff, method book'. VDLUFA-Verlag, Darmstadt, Germany, 2004.

26. Aschenbach JR, Wehning $H$, Kurze M, Schaberg E, Nieper H, Burckhardt G, et al. Functional and molecular biological evidence of SGLT-1 in the ruminal epithelium of sheep. Am J Physiol Gastrointest Liver Physiol. 2000;279:G20-7.

27. Aschenbach JR, Borau T, Gäbel G. Glucose uptake via SGLT-1 is stimulated by $\beta 2$-adrenoceptors in the ruminal epithelium of sheep. J Nutr. 2002;132: 1254-7.

28. SAS. SAS/STAT User's Guide, Version 8, SAS Institute Inc., Cary, NC, USA, 2001.

29. Leys C, Ley C, Klein O, Bernard P, Licata L. Detecting outliers: do not use standard deviation around the mean, use absolute deviation around the median. J Exp Social Psychol. 2013;49:764-6.

30. Simitzis PE, Feggeros K, Bizelis JA, Deligeorgis SG. Behavioural reaction to essential oils dietary supplementation in sheep. Biotechnol Anim Husb. 2005:21:97-103.

31. Van Bibber-Krueger CL, Miller KA, Aperce CC, Alvarado-Gilis CA, Higgins JJ, Drouillard JS. Effects of crystalline menthol on blood metabolites in Holstein steers and in vitro volatile fatty acid and gas production. J Anim Sci. 2016; 94:1170-8.

32. Patra AK, Geiger S, Braun HS, Aschenbach JR. Dietary supplementation of menthol-rich bioactive lipid compounds alters circadian eating behaviour of sheep. BMC Vet Res. 2019. https://doi.org/10.1186/s12917-019-2109-0.

33. Smeti S, Joy M, Haiji H, Alabart JL, Muñoz F, Mahouachi M, et al. Effects of Rosmarinus officinalis $L$. essential oils supplementation on digestion, colostrum production of dairy ewes and lamb mortality and growth. Anim Sci J. 2015;86:679-88.

34. Yang WZ, Ametaj BN, Benchaar C, He ML, Beauchemin KA. Cinnamaldehyde in feedlot cattle diets: intake, growth performance, carcass characteristics, and blood metabolites. J Anim Sci. 2010;88:1082-92.

35. Tager LR, Krause KM. Effects of essential oils on rumen fermentation, milk production, and feeding behavior in lactating dairy cows. J Dairy Sci. 2011 94:2455-64.

36. Moura LV, Oliveira ER, Fernandes ARM, Gabriel AMA, Silva LHX, Takiya CS, et al. Feed efficiency and carcass traits of feedlot lambs supplemented either monensin or increasing doses of copaiba (Copaifera spp) essential oil. Anim Feed Sci Technol. 2017;232:110-8.

37. Mohamadi R, Rahchamani R, Ghanbari F, Farivar F. Peppermint and pennyroyal essential oil effect on performance, rumen microbial population and some blood parameters of sheep. Iranian J Vet Med. 2017;11:75-84.

38. Tassoul MD, Shaver RD. Effect of a mixture of supplemental dietary plant essential oils on performance of periparturient and early lactation dairy cows. J Dairy Sci. 2009:92:1734-40.

39. Yoneshiro T, Saito M. Transient receptor potential activated brown fat thermogenesis as a target of food ingredients for obesity management. Curr Opin Clin Nutr Metab Care. 2013;16:625-31.

40. Valente A, Carrillo AE, Tzatzarakis MN, Vakonaki E, Tsatsakis AM, Kenny GP, et al. The absorption and metabolism of a single L-menthol oral versus skin administration: effects on thermogenesis and metabolic rate. Food Chem Toxicol. 2015:86:262-73.

41. Hosoda K, Nishida T, Park W, Eruden B. Influence of Mentha piperita L. (peppermint) supplementation on nutrient digestibility and energy metabolism in lactating dairy cows. Asian-Australas J Anim Sci. 2005;18:1721-6.

42. McKemy DD. TRPM8: the cold and menthol receptor. In: Liedtke WB, Heller $\mathrm{S}$, editors. TRP ion channel function in sensory transduction and cellular signaling cascades. Boca Raton (FL): CRC Press/Taylor \& Francis; 2007. p. 177-88. 
43. Soltan MA. Effect of essential oils supplemented on growth performance, nutrient digestibility, health condition of Holstein male calves during preand post-weaning periods. Pak J Nutr. 2009:8:642-52.

44. Chaves AV, Stanford K, Dugan MER, Gibson LL, McAllistler TA, Van Herk F, et al. Effects of cinnamaldehyde, garlic and juniper berry essential oils on rumen fermentation, blood metabolites, growth performance, and carcass characteristics of growing lambs. Livest Sci. 2008;117:215-24.

45. Kumar P, Patra AK, Mandal GP, Samanta I, Pradhan S. Effect of black cumin seeds on growth performance, nutrient utilization, immunity, gut health and nitrogen excretion in broiler chickens. J Sci Food Agric 2017;97:3742-51.

46. Braun HS, Schrapers KT, Mahlkow-Nerge K, Stumpff F, Rosendahl J. Dietary supplementation of essential oils in dairy cows: evidence for stimulatory effects on nutrient absorption. Animal. 2018;13:518-23.

47. Raggio G, Pacheco D, Berthiaume R, Lobley GE, Pellerin D, Allard G, et al. Effect of level of metabolizable protein on splanchnic flux of amino acids in lactating dairy cows. J Dairy Sci. 2004;87:3461-72.

48. Murray RK, Granner DK, Mayes PA, Rodwell WW. Harper's biochemistry. New York: McGraw-Hill; 2000.

49. Cruz OTB, Valero MV, Zawadzki F, Rivaroli DC, do Prado RM, Lima BS, et al. Effect of glycerine and essential oils (Anacardium occidentale and Ricinus communis) on animal performance, feed efficiency and carcass characteristics of crossbred bulls finished in a feedlot system. Italian J Anim Sci. 2014;13:3492.

50. Pour HA, Naserian AA, Vakili AR, Tahmasbi AM. The effect of Mentha piperita essential oil on biochemical and haematological parameters of rams. Res Opin Anim Vet Sci. 2016;6:181-4.

51. Baumgartner W, Pernthaner A. Influence of age, season, and pregnancy upon blood parameters in Austrian karakul sheep. Small Rumin Res. 1994;13: 147-51.

52. Trabalza-Marinucci M, Brandi G, Rondini C, Avellini L, Giammarini C, Costarelli S, et al. A three-year longitudinal study on the effects of a diet containing genetically modified Bt176 maize on the health status and performance of sheep. Livest Sci. 2008;113:178-90.

53. Abe S, Maruyama N, Hayama K, Inouye S, Oshima H, Yamaguchi H. Suppression of neutrophil recruitment in mice by geranium essential oils. Mediat Inflamm. 2004;13:21-4.

54. Maruyama N, Sekimoto $Y$, Ishibashi $H$, Inouye $S$, Oshima $H$, Yamaguchi $H$, et al. Suppression of neutrophil accumulation in mice by cutaneous application of geranium essential oil. J Inflamm. (Lond). 2005;2:1.

55. Gomes BS, Neto BPS, Lopes EM, Cunha FVM, Araújo AR, Wanderley CWS, et al. Anti-inflammatory effect of the monoterpene myrtenol is dependent on the direct modulation of neutrophil migration and oxidative stress. Chem Biol Interact. 2017;273:73-81.

56. Rozza AL. Meira de Faria F, Souza Brito AR, Pellizzon CH. The gastroprotective effect of menthol: involvement of anti-apoptotic, antioxidant and anti-inflammatory activities. PLoS One. 2014;9:e86686.

57. Ghasemi-Pirbaluti M, Motaghi E, Bozorgi $\mathrm{H}$. The effect of menthol on acute experimental colitis in rats. Eur J Pharmacol. 2017:805:101-7.

58. Juergens UR, Stober $M$, Vetter $H$. The anti-inflammatory activity of Lmenthol compared to mint oil in human monocytes in vitro: a novel perspective for its therapeutic use in inflammatory diseases. Eur J Med Res. 1998:3:539-45.

59. Aschenbach JR, Bhatia SK, Pfannkuche H, Gäbel G. Glucose is absorbed in a sodium-dependent manner from forestomach contents of sheep. J Nutr. 2000;130:2797-801.

60. Atasoglu C, Gäbel G, Aschenbach JR. Apical sodium-glucose co-transport can be regulated by blood-borne glucose in the ruminal epithelium of sheep (Ovis aries, merino breed). Br J Nutr. 2004;92:777-83.

61. Shirazi-Beechey SP, Hirayama BA, Wang Y, Scott D, Smith MW, Wright EM. Ontogenic development of lamb intestinal sodium-glucose co-transporter is regulated by diet. J Physiol. 1991;43:699-708.

62. Shirazi-Beechey SP. Intestinal sodium-dependent D-glucose co-transporter: dietary regulation. Proc Nutr Soc. 1996;55:167-78.

63. Dyer J, Barker PJ, Shirazi-Beechey SP. Nutrient regulation of the intestinal $\mathrm{Na}^{+}$/glucose co-transporter (SGLT1) gene expression. Biochem Biophys Res Commun. 1997;23:624-9

64. Sun Q, Liu D, Guo S, Chen Y, Guo Y. Effects of dietary essential oil and enzyme supplementation on growth performance and gut health of broilers challenged by Clostridium perfringens. Anim Feed Sci Technol. 2015: 207:234-44
65. Klinger S, Schröder B, Gemmer A, Reimers J, Breves G, Herrmann J, et al. Gastrointestinal transport of calcium and glucose in lactating ewes. Physiol Rep. 2016;4. https://doi.org/10.14814/phy2.12817.

66. Mastrototaro L, Sponder G, Saremi B, Aschenbach JR. Gastrointestinal methionine shuttle: priority handling of precious goods. IUBMB Life. 2016; 68:924-34.

67. Johnston K, Sharp P, Clifford M, Morgan L. Dietary polyphenols decrease glucose uptake by human intestinal Caco-2 cells. FEBS Lett. 2005;579:1653-7.

68. Penner GB, Aschenbach JR, Wood K, Walpole ME, Kanafany-Guzman R, Hendrick $S$, et al. Characterizing barrier function among regions of the gastrointestinal tract in Holstein steers. Anim Prod Sci. 2014;54:1282-7.

69. Aschenbach JR, Oswald R, Gäbel G. Transport, catabolism, and release of histamine in the ruminal epithelium of sheep. Pflügers Arch. 2000;440:171-8.

70. The European Commission (2018). Commission Implementing Regulation (EU) 2018/245 of 15 February 2018 concerning the authorisation of menthol, d-carvone, menthyl acetate, d,l-isomenthone, 3-methyl- 2-(pent2(cis)-enyl)cyclopent-2-en-1-one, 3,5,5-trimethylcyclohex-2-en-1-one, $d$ fenchone, fenchyl alcohol, carvyl acetate, dihydrocarvyl acetate and fenchyl acetate as feed additives for all animal species. J Europ Union L53, 87-104.

\section{Ready to submit your research? Choose BMC and benefit from:}

- fast, convenient online submission

- thorough peer review by experienced researchers in your field

- rapid publication on acceptance

- support for research data, including large and complex data types

- gold Open Access which fosters wider collaboration and increased citations

- maximum visibility for your research: over $100 \mathrm{M}$ website views per year

At BMC, research is always in progress.

Learn more biomedcentral.com/submissions 